\title{
Establishing the reliability and validity of the ASSIST questionnaire: a South African sample perspective
}

\section{Sibongile Simelane-Mnisi ${ }^{1}$, Andile $\mathbf{M j i}^{2}$}

${ }^{1}$ Department of Teaching and Learning with Technology, Tshwane University of Technology, Pretoria

${ }^{2}$ Faculty of Humanities, Tshwane University of Technology, Pretoria

\section{South Africa}

Correspondence: Sibongile Simelane-Mnisi, Building 5-221, Tshwane University of Technology, Private Bag X680, Pretoria, 0001. South Africa. E-mail: simelanes@ tut.ac.za

(C) Education \& Psychology I+D+i and Ilustre Colegio Oficial de la Psicología de Andalucía Oriental (Spain) 


\section{Abstract}

Introduction. The Approaches and Study Skills Inventory for Students (ASSIST Short Version) was used to better understand the students' approaches to learning in a mathematics classes.

Method. Quantitave method was used in this study. Participants were 345 first and second year mathematics students from a university in the Gauteng province of South Africa. The reliability of the ASSIST Short Version was computed by Cronbach's alpha. The coefficient values from scores of each group are presented with respect to the preliminary data phase and the post-intervention data phase. The validity of the ASSIST questionnaire was computed using content validity which involved the computation of factor analysis and confirmatory factor analysis which involved checking whether the theory developed constructs of Deep, Strategic and Surface approaches.

Results. The results show that the reliability of ASSIST Short Version, the alpha values ranged between .75 and .83 (preliminary data phase) as well as .65 and .82 (post-intervention data phase). For the content validity the results show that the value of $\mathrm{KMO}=.769$ was acceptable while the Bartlett's test of sphericity was also statistically significant $(\mathrm{p}<0.001)$. In determining the factor structure from the data, Maximum likelihood factor analysis with Direct oblimin rotation was specified. Construct validity was ascertained by computing through AMOS a confirmatory factor analysis (CFA) using data from the post-intervention data phase. The results show that the Chi square $(\chi 2)$ was statistically significant $[\chi 2=210.94, \mathrm{df}=132, \mathrm{p}<.0001]$. The goodness of fit statistics were: $\mathrm{TLI}=.948$, the CFI $=.947$, and the RMSEA $=.054$. The results also shows the standardized parameter estimates of the model from the ASSIST questionnaire.

Discussion and Conclusion. In terms of reliability of scores from the instrument, the alpha values were accepted for this study because they were comparable to those reported in literature. Validity was computed through factor analysis (content validity) and confirmatory factor analysis (construct validity). Before computing the factor structure of the ASSIST, Kaiser-Meyer-Olkin (KMO) and Bartlett's test of sphericity were determined. The two values reported in this study indicated that computing the factor analysis was appropriate for the data. Using the Direct oblimin rotation consistently as in reported literature, a three factor solution was accepted in this study. Because these factors were consistent with those reported in literature content validity was acceptable in this study.

Keywords: Reliability, validity, students approach to learning, study skills inventories and ASSIST. 


\section{Resumen}

Introducción. Para comprender mejor los enfoques de aprendizaje de los estudiantes en las clases de matemáticas, se utilizó el Inventario de Aproximaciones y Estudios de Habilidades para Estudiantes (ASSIST Short Version)

Método. Los participantes fueron 345 estudiantes de matemáticas de primer y segundo año de una universidad en la provincia de Gauteng (Sudáfrica). La fiabilidad de la versión corta de ASSIST se calculó con el alfa de Cronbach. Los valores de los coeficientes de las puntuaciones de cada grupo se presentan con respecto a la fase de datos preliminares y la fase de datos posteriores a la intervención. La validez del cuestionario ASSIST se calculó utilizando la validez del contenido, lo que implicó el cálculo del análisis factorial exploratorio y confirmatorio.

Resultados. Los resultados muestran que en la fiabilidad de la versión corta de ASSIST, los valores alfa oscilaron entre 0,75 y 0,83 (fase de datos preliminares), así como 0,65 y 0,82 (fase de datos posteriores a la intervención). Respecto a la validez del contenido, los resultados muestran que el valor de $\mathrm{KMO}=.769$ fue aceptable mientras que el test de Bartlett de esfericidad también fue estadísticamente significativo ( $\mathrm{p}<0.001$ ). Para determinar la estructura de factores a partir de los datos, se especificó el análisis del factor de máxima verosimilitud con rotación Directa Oblimin. La validez constructiva se determinó mediante la estimación a través de AMOS, un análisis factorial confirmatorio (CFA) utilizando datos de la fase de datos post-intervención. Los resultados muestran que el Chi cuadrado $(\chi 2)$ fue estadísticamente significativo $\left[\chi^{2}=210.94, \mathrm{df}=132, p<.0001\right]$. Las estadísticas de bondad de ajuste fueron: $\mathrm{TLI}=.948$, el CFI $=.947$, y el RMSEA $=.054$. Los resultados también muestran las estimaciones de los parámetros estandarizados del modelo a partir del cuestionario ASSIST.

Discusión y Conclusión. En términos de fiabilidad de las puntuaciones del instrumento, los valores alfa fueron aceptados para este estudio porque eran comparables a los reportados en la literatura. La validez se calculó a través del análisis de factores (validez de contenido) y el análisis factorial confirmatorio (validez de constructo). Los dos valores informados en este estudio indicaron que el cálculo del análisis factorial era apropiado para los datos. Usando la rotación directa oblimin de forma consistente como en la literatura, se aceptó una solución de tres factores en este estudio. Debido a que estos factores eran consistentes con los reportados en la literatura, la validez de contenido fue aceptable en este estudio.

Palabras clave: Fiabilidad, validez, enfoque de los estudiantes para el aprendizaje, inventarios de habilidades de estudio y ASSIST. 


\section{Introduction}

Research focusing on approaches to learning has over the years been conducted among university students. The approach to learning paradigm (Biggs, 1987, Martin \& Säljö, 1976) is one of the most widely used frameworks for understanding student learning in higher education. The conception of approaches to learning is based upon the original research of Martin \& Säljö (1976), who identified individual differences in approaches to learning based on qualitative analysis of student learning. Researchers such as (Biggs, 1987; Entwistle, McCune \& Trait, 2006; Entwistle, 1996; Martin \& Säljö 1976) are amongst the first researchers to strategise the students approach to learning, the quality of their learning outcomes and their prior experiences. Several studies (Abedina, Jaafarb, Husainc, \& Abdullahd, 2013) continuously provide constant evidence that individual differences in how students approach learning exist such as deep, strategic and surface (Gadelrab, 2011; Teixeira, Gomes, \& Borges, 2013; Venkatesh, Croteau, \& Rabah, 2014). It is pointed out that in order to obtain high-quality learning outcome (Buckley, Pitt, Norton \& Owens, 2010), lecturers require to understand student learning, specifically how students adjust their learning tasks, their aims and strategies, and how these influence the quality of their learning outcomes (Martin \& Säljö, 1976). Entwistle, (2000) is of an opinion that students approach to learning and studying is the manner in which students think and believe that learning involves and how they go about with everyday academic tasks or the way they carry out their studying. He argues that student learning, studying and level of understanding is influenced by teaching, assessment and the teaching environment (Entwistle, 2000). Student approach to learning was then divided into three categories deep, surface and strategic approaches to learning, which bring learning process and assessment procedures into a major role (Biggs, 1994; Martin \& Säljö, 1976; Entwistle, 2000; Entwistle, et al., 2006).

It is pointed out that a quality learning experience in HEIs should consider how student approach their learning and the effective teaching as far as content is concern (Roblyer, McDaniel, Webb, Herman, \& Witty, 2010). Entwistle and Ramsden's (1983) concepts of deep and surface approaches to learning are attractive because of their influence in teaching and learning today and their association with constructivist pedagogy. The deep learning approach is about learning the facts in relation to concepts and it includes monitoring the development of one's own understanding (Entwistle, et al., 2006; Price, et al., 2011). Mogashana, Case and Marshall (2012); Abedina, et al., (2013) pointed out that the major motivation in 
strategic approach is achieving rather than ideas and interest (deep approach) or fear of failure (surface approach). Hailikari and Parpala (2014) and Duff (2004) argue that students in surface learning approach often learn to remember facts, identify and focus on what they were thought. Bolkan, Goodboy, and Griffin (2011) report the relations between learning approach and academic achievement. Usually, strategic and deep approach are positively associated with high achievements and negatively related to surface approach (Bolkan, et al., 2011).

Approaches to learning have later been subjected to quantitative research by means of diverse inventories (Mogashana, et al., 2012). These instruments measure what the student usually does when approaching a learning situation (Gadelrab, 2011). Some of the measuring instruments that have been used to measure students approaches to learning in higher education are Revised Approach to Learning and Studying Inventory (RASI), Study Process Questionnaire (SPQ), Approaches to Studying Inventory (ASI) and Approach and Studying Inventory for Students (ASSIST). In the current study students' approach to learning and studying was identified by using the ASSIST Short Version with 18 items.

It is mentioned that validity and reliability are two important indicators for any type of mental measurement (Miller, n.d.; Speth Namuth, \& Lee, 2007; Tavakol \& Dennick, 2011). In fact, three aspects of reliability, namely: stability, equivalence and internal consistency have been identified (Miller, n.d.). Miller (n.d.) and Reynaldo and Santos (1999) define reliability as the extent to which a questionnaire, test, observation or any measurement procedure produces the same results on repeated trials. Tavakol and Dennick (2011) state that before a test can be applied for research investigation purposes internal consistency should be determined to ensure validity. In the current study, IBM SPSS 21 was used for calculating the internal consistency of items on a scale, Cronbach's alpha or $\alpha$.

This article reports on the reliability and validity of ASSIST Short version with first and second year mathematics students from a university in the Gauteng province of South Africa. Firstly, the researchers started by determining the internal consistency reliability of the ASSIST Short Version computed by Cronbach's (1951) alpha. Secondly, we will present the coefficient values from scores of each group with respect to the preliminary data phase and the post-intervention data phase. Finally, we will determine the factor structure from the data, Maximum likelihood factor analysis with Direct oblimin rotation was specified. 


\section{Related work}

\section{Student approach to learning and studying}

Researchers such as (Biggs, 1987); (Entwistle, 1996); (Entwistle, et al., 2006); (Martin \& Säljö, 1976) were amongst the first researchers to outline the students' approaches to learning, the quality of their learning outcomes and their prior experiences. Biggs (1994; 1987) refers to reproductive and transformational strategy as learning approach used in higher education. Säljö (1981) argues that learning approaches are similar to the one developed by Biggs. Other two learning approach were serialists and holists learning approaches (Säljö, 1981). Student in serialist /holist approaches show memorising and organising strategies. Several studies continuously provide evidence that individual differences in how students approach learning exist, such as deep, strategic and surface learning (Simelane, Mji, \& Mwambakana, 2011; Teixeira, et al., 2013; Venkatesh, et al., 2014).

It is pointed out (Buckley, et al., 2010) that in order to obtain high-quality learning outcomes, lecturers needs to understand student learning, specifically how students adjust their learning tasks, their aims and strategies, and how these influence the quality of their learning outcomes (Martin \& Säljö, 1976). In this regard, it is argued that students' awareness of their learning environment is related to their approach to learning (Abedina et al., 2013; Trigwell, Prosser, \& Waterhouse, 1999). Tied to this, it is pointed out that a student's choice of approach is influenced by the content, the context and the demands of particular learning activities (Price, et al., 2011). In this regard, it is opined that these differences in turn have a powerful influence on many features of daily learning and teaching (Gadelrab, 2011). For lecturers to promote more conceptual, deeper forms of learning, they need to understand how students approach learning (Teixeira, et al., 2013).

When students adopt these approaches to learning, it encourages their belief systems, such as success expectations and self-regulatory skills (Hailikari \& Parpala, 2014). Regarding students' belief, their approaches to learning were then divided into three categories, namely deep, surface and strategic approaches to learning, which gives the learning process and assessment procedures a major role (Biggs, 1987; Biggs, 1994; Entwistle, 2000, Entwistle, et al., 2006; Säljö, 2004). It is indicated that students could approach their courses in one of the three ways surface, deep or strategic (Mnisi, 2015). 


\section{Surface Learning Approach}

The aim of surface learning approach is to cope with the task which leads to rote learning and memorisation (Abedina, et al., 2013; Price, et al., 2011). In order for students to work with more complex principles or apply deep learning principles, students first need to try to grasp more basic principles which require them to memorise and remember. Felder and Brent (2005) argue that student who employ surface approach to learning tend to memorise facts, do not fit them into context and they aim for routine solution methods without attempting to understand their original and limitation. It has been stated that students following the surface learning approach often learn to remember facts, identify aspects and focus on what they were taught (Abedina et al., 2013; Warren, 2004).Regarding this, it has been stated that these students face the challenge in forming a bigger picture and aiming at reproducing the knowledge (Hailikari \& Parpala, 2014). Surface learners have a reproductive conception of learning and are extrinsically motivated mostly by the results (Roblyer, McDaniel, Webb, Herman, \& Witty, 2010). In this regard, it is pointed out that surface approach learners study through fear of failure with the aim of rote learning (Mattick, Dennis, \& Bligh, 2004).

\section{Deep Learning Approach}

The deep learning approach is about learning the facts in relation to concepts and it includes monitoring the development of one's own understanding (Entwistle, et al., 2006; Price, et al., 2011). It is pointed out that the deep learning approach students, think critically and deeply to form their own conclusions about course material (Bolkan, et al., 2011). In essence, literature reveals that students with a deep approach to learning aim to understand the teaching and learning environment as well as subject matter more positively than students with surface approach (Hailikari \& Parpala, 2014). Students in this category focus on understanding the course material instead of relying on memorisation (Felder \& Brent, 2005). These students study through intrinsic interest to maximise meaning (Mattick et al., 2004). It is argued that the socio-constructivist theory recommends that deep learning approaches are more liable than surface approaches to direct students to understanding and enduring learning (Ditcher, 2001).

\section{Strategic Learning Appraoch}

In the strategic learning approach the emphasis is to achieve the highest possible results by using good time management and organised study methods (Entwistle, 2000), students combine aspects of the deep or surface approach. Depending on approach, deep ap- 
proach or surface approach, this would lead to top achievement (Mogashana, et al., 2012). In this regard, it is reported that academic performance tends to be positively associated with the strategic learning approach (Bolkan, et al., 2011). It is mentioned that students following strategic learning approach are efficient in their learning and they are well organised (Felder \& Brent, 2005) These authors further state that these students following the strategic learning approach carefully assess the level of effort they need to relate to so that they could achieve their ambition. In fact, (Mattick et al., 2004) refers to strategic approach as an achieving approach because strategic approach learners study to increase success in assessments through effective use of space and time. This leads students to adopt self-regulation as well as monitoring one's studying effectiveness (Entwistle, 2000). In this category students do whatever it takes to get to the top results (Mnisi, 2015; Felder \& Brent, 2005).

\section{Educational Technologies and Students' Approaches}

Research shows a shortage of studies that investigated students' approaches to learning with the incorporation of educational technologies (Buckley, et al., 2010; Tlhapane \& Simelane, 2010). These authors reveal that this type of research is mostly done in a face-toface learning environment. However, it is reported that students who follow the deep and strategic approaches to learning were more comfortable with a blended learning environment than students who adopted a surface approach (Buckley, et al., 2010). Similarly, it was also stated that there were no significant relations between study approaches and perceptions of information communication technology (ICT) usefulness, although students using the deep learning approach indicated a higher appreciation of ICT integration in a course (Venkatesh, et al., 2014).

\section{Student approach to learning and studying measuring instruments}

Student learning inventories are used in education as tools to identify at-risk students. These study learning inventories contribute to the measurement of students' study methods and approaches by offering persuading empirical evidence important to inform policy decisions in higher education (Teixeira, et al., 2013). Various approaches to learning and studying measuring instrument have been developed and implement in higher education institutions (Mogashana, et al., 2012). These instruments measure what the student usually does when approaching a learning situation (Abedina, et al., 2013; Gadelrab, 2011). Some of the measuring instruments that have been used to measure students approaches to learning in higher edu- 
cation are the Learning Approached to Studying Questionnaire, Revised Approach to Learning and Studying Inventory (RASI) (Duff, 2004; Mattick, et al., 2004), Study Process Questionnaire (SPQ) (Biggs, 1994) and Raven's Standardised Progressive Matrices (sets A-E).

Entwistle and Ramsden (1983) developed the approaches to studying inventory (ASI) at the University of Lancaster in Britain. This instrument indicates the relative strengths of students' approaches in three main dimensions - deep, surface and strategic (Diseth \& Martinsen, 2003; Gadelrab, 2011; Speth, Lee \& Hain, 2003). The ASI comprised of 64 items within 16 subscales (Mattick et al., 2004). The ASI was refined by RASI and ASSIST, because of its reliability and validity and troubles in reproducing the intended three-factor structure (Diseth, 2001). Subsequently, the Centre for Research on Learning and Instruction in the University of Edinburgh in 1997 developed ASSIST which comprised of 52 items (Entwistle, et al., 2006). Later, ASSIST was also refined to the shorter version which comprises of 18 items and 3 factors (Entwistle, et al., 2006). In the current study, student approach to learning and studying was identified by using the Approaches and Study Skills Inventory for Students (ASSIST)-Short Version. Students were categorised according to their preferred approach to learning and studying.

\section{Validity and reliability}

Morse, Barrett, Mayan, Olson and Spier (2002) point out that research is worthless, become fiction and loses its value when there no rigor. Therefore, in all research methods reliability and validity is given great attention (Morse et al., 2002). It is argued that validity and reliability are two important indicators for any type of mental measurement (Miller, n.d.; Speth, Namuth, \& Lee, 2007; Tavakol \& Dennick, 2011). In fact, in positivist perspective or quantitative research the criteria to reach the aim of rigor are internal validity, external validity, reliability, and objectivity (Golafshani, 2003; Morse et al., 2002). Speth et al., (2007) define reliability as the test or questionnaire measures what it claims to measure consistently, either in terms of consistency over time, or that the items combined to produce scores have high enough positive inter-item correlations to produce meaningful scores.

Miller (n.d.) identifies three aspects of reliability, namely: stability, equivalence and internal consistency. He states that stability, occurs when the same or similar scores are obtained with repeated testing with the same group of respondents (Miller, n.d.). He mentions the equivalence is the amount of agreement between two or more instruments that are administered at nearly the same point in time (Miller, n.d.). He also points out that internal con- 
sistency relates to the degree to which items on the test or instrument are measuring the same thing (Miller, n.d.). A coefficient of reliability could be calculated based on several formulas. Therefore, for calculating the internal consistency of items on a scale, Lee Cronbach of Stanford University developed a formula called Cronbach's alpha or $\alpha$ (Cronbach, 1951; Speth et al., 2007; Tavakol \& Dennick, 2011). In fact, the computation of alpha is based on the reliability of a test relative to other tests with similar number of items, and measuring the same construct of interest (Marland, Dearlove, \& Carpenter, 2015; Reynaldo \& Santos, 1999; Tavakol \& Dennick, 2011).

On the other hand, validity is concerned with the extent to which the instrument measures what it intended to measure (Golafshani, 2003; Miller, n.d.; Tavakol \& Dennick, 2011). Miller (n.d.) identifies various types of validity, namely content validity, face validity, criterion-related validity (or predictive validity), construct validity, factorial validity, concurrent validity, convergent validity and divergent validity. Literature states that a test has validity if it measures what it intends to measure and validity could be tested in different ways, depending on the test and its objectives use (Ro, Merson, Lattuca, \& Terenzini, 2015; Speth et al., 2007). In fact, any research instrument to be used should be validated from scratch in each new context (Ro et al., 2015; Speth et al., 2007). Tavakol and Dennick (2011) argue that an instrument cannot be valid unless it is reliable It is worth also noting that the reliability of an instrument does not depend on its validity.

\section{Method}

\section{Participants}

The sample selected for this study was a convenience sample in that the first author works at the same campus with the participants. The participants were selected because they were available and accessible (McMillan \& Schumacher, 2001). Participants were 345 first and second year mathematics students from a university in the Gauteng province of South Africa. The students were taking first year mathematics including basic math which includes exponents, functions, wave theory, radiant measure, trigonometry and hyperbolic function. The following topics, namely, matrices, vectors, complex numbers or mensuration, differentiation, and integration were also included in the syllabus. The second-year mathematics syllabus covers Newton-Raphson, Trapezium and Simpson, Gauss elimination, differentiation of inverse trigonometric and hyperbolic functions, parametric functions, optimisation and Maclaurin series, integration, partial fractions, chain rule and rate of change, direct integration and 
separation of variables. There were $146(42.3 \%)$ women and $96(27.8 \%)$ men, while 103 (29.9\%) did not disclose their sex. Their ages ranged between 17 years and 44 years $(\mathrm{M}=$ 21.3, SD = 3.14). Of the total, $84(24.3 \%)$ did not indicate their ages. More than half of the participants191 (55.4\%) were taking first year mathematics for the first time. There were 68 (19.7\%) participants who indicated that they had failed first year mathematics at least once while about a quarter $(24.9 \%)$ did not disclose this information. The 345 students were divided into three groups based on the qualification they were pursuing. For instance, the first group named MI - Group A $(\mathrm{n}=105)$ was made up of students studying towards an electrical engineering qualification. The second group, named MII - Group B ( $n=49)$ was made up of students studying towards a chemistry qualification. The third group, named MII- Group C (n = 191) was made up of students studying towards an electrical engineering and surveying qualification. The group numbers were different because attending mathematics lectures also depended on other courses they were registered for. The groups were taught by the same lecturer however.

In MI - Group A in terms of sex, 14 (13.3\%) were women and 29 (27.6\%) men while the rest did not disclose this information. With respect to ages, $45.7 \%$ of the participants' ages ranged between 17 and 31 years $(\mathrm{M}=19.9$ years, $\mathrm{SD}=2.5)$. Here 57 did not indicate their ages. There were $41(39.0 \%)$ participants who were registered for the very first time in the mathematics first year course. Also, seven indicated that they had failed the course at least once while rest $(61 \%)$ did not disclose their registration status. In MI - Group B, there were $24(49.0 \%)$ women and $22(44.9 \%)$ men while the rest did not disclose this information. With respect to ages, $93.9 \%$ of the participants' ages ranged between 19 and 44 years $(M=23.8$ years, SD $=4.8)$. Here, 3 did not indicate their ages. There were $24(49.0 \%)$ participants who were registered for the very first time in this course. Also, 12 (24.5\%) indicated that they had failed the mathematics course at least once while rest $(26.5 \%)$ did not disclose their registration status. In MI - Group C, there were 108 (56.5\%) women and 45 (23.6\%) men while the rest did not disclose this information. With respect to their ages, $87.4 \%$ of the participants' ages ranged between 18 and 35 years $(M=21.0$ years, $S D=2.2)$ with 24 not indicating their ages. There were $126(66.0 \%)$ participants who were registered for the very first time in this mathematics course. Also, 49 (25.6\%) indicated that they had failed the course at least once while rest $(8.4 \%)$ did not disclose their registration status.

\section{Instrument and Procedure}


In this study the Approaches and Study Skills Inventory for Students (ASSIST) - Short Version was used (Entwistle, et al., 2006; Speth, et al., 2007). Before using the ASSIST Short Version in South Africa, a letter requesting permission to do this was written to Professor Entwistle who granted this. The ASSIST - Short Version is an 18 - item inventory comprising three subscales that measure deep, strategic and surface approaches (Entwistle, et al., 2006; Speth, et al., 2007). In responding to the instrument, students were requested to indicate their choice on 5-point Likert-type rating scale anchored by 1: Disagree and 5: Agree. The first subscale (deep approaches) is about students who want to understand ideas on their own, relating ideas to previous knowledge and experience, looking for patterns and underlying principles. A typical example of an item from this subscale was "When I' $m$ working on a new topic, I try to see in my own mind how all the ideas fit together". The second subscale (strategic approaches) is about students who are students who are systematic and organised, they manage their time cautiously, achieving is their motivational aspect and they pay more attention to assessment demands. A typical example of an item from this subscale is "I organise my study time carefully to make the best use of it". The third subscale (surface approaches) is about students who lack purpose, they are not sure what is important in lecturers they memorise unrelated facts, they always worry and panic about their work, they have fear of failure and they do not think outside the box they focus on the syllabus minimum requirements. A typical example of an item from this subscale was "I'm not really sure what's important in lectures, so I try to get down all I can".

In terms of the reliability of scores obtained from the ASSIST - Short Version, a number of studies have reported similar findings. For example in a study in the US, alpha values for the three subscales ranged between 0.65 and 0.75 (Speth et al., 2007). Specifically, the alpha values were: deep approach $(\alpha=.65)$, strategic approach $(\alpha=.75)$ and the surface ap$\operatorname{proach}(\alpha=.70)$.

Literature reported that there are few studies that have looked at the factor structure of all three sections of ASSIST Short Version (Entwistle, et al., 2006). The study in six British universities shows the alpha values for the three subscales ranged between 0.80 and 0.87 (Entwistle, et al., 2006). Specifically, the alpha values were: deep approach $(\alpha=.84)$, strategic approach $(\alpha=.80)$ and the surface approach $(\alpha=.87)$. A study in Norway used ASSIST 52 item, alpha values for three subscale ranged between 0.70 and 0.81 and were reported to be appropriate (Diseth, 2001). Precisely, the alpha values were deep approach $(\alpha=.78)$, strategic 
approach $(\alpha=.72)$ and the surface approach $(\alpha=.64)$ (Diseth, 2001; Diseth \& Martinsen, 2003). Diseth (2001) also shows that the alpha values for some of the subscales were relatively low, but were considered sufficient considering that each subscale involves only four items. Alpha values between 0.57 and 0.72 were reported in 9 of 13 subscale; other four subscales fell between 0.41 and 0.51 (Diseth, 2001).

\section{Data Collection and Analysis}

Data were collected in two phases named the preliminary data phase and the postintervention data phase. All analyses were carried out using SPSS version $21 \odot$. The reliability of scores from this instrument was determined by computing Cronbach's (1951) alpha. With regards to validity of scores from this instrument, content validity was ascertained by computing a factor analysis using the data from preliminary data phase. Furthermore, construct validity was established through a confirmatory factor analysis using the data from the postintervention data phase.

\section{Results}

\section{Scale Reliability}

Gliem and Gliem (2003, p. 89) point out that in using Likert-type scales “... it is imperative to calculate and report Cronbach's alpha coefficient for internal consistency reliability for any scales or subscales one may be using." The test of internal consistency of the ASSIST Short Version was investigated by computing Cronbach's (Cronbach, 1951) alpha. The coefficient values from scores of each group are presented here with respect to the preliminary data phase and the post-intervention data phase. In the preliminary data phase, the alpha value for the entire scale for M1 -Group C was $\alpha=0.51$. For the three subscales, the values ranged between 0.48 and 0.69. Specifically, the alpha values were: $\alpha=0.51$ (Deep Approach); $\alpha=0.69$ (Strategic Approach) and $\alpha=0.48$ (Surface Approach). For MII - Group D the alpha value for the entire scale was $\alpha=0.50$. For the three subscales, the values were: $\alpha=0.58$ (Deep Approach); $\alpha=0.44$ (Strategic Approach) and $\alpha=0.51$ (Surface Approach). For MII Group E the alpha value for the entire scale was $\alpha=0.58$. For the three subscales, the values were: $\alpha=0.56$ (Deep Approach); $\alpha=0.66$ (Strategic Approach) and $\alpha=0.47$ (Surface Approach).

In the post-intervention data phase the alpha value for the entire scale for MI - Group $\mathrm{C}$ was $\alpha=0.77$. For the three subscales, the values ranged between 0.55 and 0.85 . Specifical- 
ly, the alpha values were: $\alpha=0.74$ (Deep Approach); $\alpha=0.85$ (Strategic Approach) and $\alpha=$ 0.55 (Surface Approach). For MII - Group D the alpha value for the entire scale was $\alpha=0.73$. For the three subscales, the values were: $\alpha=0.70$ (Deep Approach); $\alpha=0.78$ (Strategic Approach) and $\alpha=0.70$ (Surface Approach). For MII - Group E the alpha value for the entire scale was $\alpha=0.67$. For the three subscales, the values were: $\alpha=0.61$ (Deep Approach); $\alpha=$ 0.77 (Strategic Approach) and $\alpha=0.51$ (Surface Approach).

\section{Scale Validity}

In ensuring the validity of the ASSIST questionnaire, two computations were carried out. The first, relating to content validity involved the computation of factor analysis. The second, relating to confirmatory factor analysis involved checking whether the theory developed constructs of Deep, Strategic and Surface approaches would be replicated in the calculated model. Content validity was ascertained by determining the factor structure of this instrument using data from the preliminary data phase. Initially, Kaiser-Meyer-Olkin (KMO) and Bartlett's test of sphericity were computed. These two values provide an indication of whether computing a factor analysis is appropriate for the data or not (Field, 2005). The value of $\mathrm{KMO}=.769$ was acceptable while the Bartlett's test of sphericity was also statistically significant $(p<0.001)$.

In determining the factor structure from the data, Maximum likelihood factor analysis with Direct oblimin rotation was specified. In the initial analysis default settings in SPSS such as the eigenvalue greater than unity criterion as well as the scree plot were specified. The rotated matrix produced a five factor solution that explained $48.5 \%$ of total variance. Table 4.6 shows that the first factor with an eigenvalue of 3.48 had four items. These items were consistent with the Deep approaches. The highest loading item was: Before tackling a problem or assignment, I first try to work out what lies behind it. The second factor with an eigenvalue of 1.74 had five items. These items were consistent with the Surface approach (4 items) and Deep approach (1 item). The highest loading item was: I often worry about whether I'll ever be able to cope with the work properly. The third factor with an eigenvalue of 1.30 had two items. These items were consistent with the Surface approach. The highest loading item was: There's not much of the work here that I find interesting or relevant. The fourth factor with an eigenvalue of 1.16 had three items. These items were consistent with the Strategic approach. The highest loading item was: I put a lot of effort into studying because I'm determined to do well. The fifth factor with an eigenvalue of 1.05 had four items. These items were consistent 
with the Strategic approach (3 items) and the Deep approach (1 item). The highest loading item was: When I read, I examine the details carefully to see how they fit in with what's being said. Because the factor analysis produced Factor 3 with two items significantly loading, this indicated that it was not the best solution.

A decision to examine a three factor solution was made as this is the number reported in literature about the ASSIST questionnaire. Also, an inspection of the scree plot seemed to indicate that a three factor solution was appropriate.

Table 1 shows that the first factor with an eigenvalue of 4.71 had one item. This item was consistent with the Surface approach. The item was: There's not much of the work here that I find interesting or relevant. The second factor with an eigenvalue of 2.12 had eleven items. These items were consistent with the Strategic approach (6 items) and Deep approach (5 items). The highest loading item was: When I read, I examine the details carefully to see how they fit in with what's being said. The third factor with an eigenvalue of 1.22 had six items. These items were consistent with the Surface approach (5 items) and Deep approach (1 item). The highest loading item was: I often worry about whether I'll ever be able to cope with the work properly. This factor solution was also not the best so it was declared unacceptable.

Construct validity was ascertained by computing through AMOS a confirmatory factor analysis (CFA) using data from the post-intervention data phase. The sample size for this analysis was 209 with no missing data. CFA “... is theory driven ... When a CFA is conducted, the researcher uses a hypothesized model to estimate a population covariance matrix that is compared with the observed covariance matrix" (Schreiber, Stage, King, Nora, \& Barlow, 2006, p. 323). In fact, it is argued that CFA is ideal because it allows a researcher to specify the number of factors in a model based on what is reported in literature (Stevens, 2002; Tabachnick \& Fidell, 2001). What this suggests is that the three factor structure of the ASSIST that theory refers to was tested against the data collected in this study. The aim was to determine whether the same factors would be established. If that was to be the case, then construct validity of the ASSIST from of a South African sample perspective would be assured. In computing the CFA, the Maximum likelihood method was selected as recommended by (Arbuckle, 2004). 
Table 1. Direct oblimin rotated structure matrix relating to the extracted items of the ASSIST questionnaire

\begin{tabular}{|c|c|c|c|c|c|c|c|c|c|c|c|}
\hline \multirow{2}{*}{\multicolumn{2}{|c|}{$\begin{array}{lc} & \text { Items }\end{array}$}} & \multicolumn{10}{|c|}{ Factor } \\
\hline & & 1 & 2 & 3 & 4 & 5 & 1 & 2 & 3 & 1 & 2 \\
\hline 9. & I put a lot of effort into studying because I'm determined to do well. & & & & .633 & & & .571 & & .620 & \\
\hline 10. & When I'm working on a new topic, I try to see in my own mind how all the ideas fit together. & .546 & & & & & & .592 & & .578 & \\
\hline 17. & When I read, I examine the details carefully to see how they fit in with what's being said. & & & & & -.733 & & .606 & & .571 & \\
\hline 5. & I work steadily through the term or semester, rather than leave it all until the last minute. & & & & & -.419 & & .509 & & .527 & \\
\hline 6. & Before tackling a problem or assignment, I first try to work out what lies behind it. & .591 & & & & & & .508 & & .481 & \\
\hline 3. & I organise my study time carefully to make the best use of it. & & & & & -.395 & & .503 & & .475 & \\
\hline 11. & I don't find it at all difficult to motivate myself. & & & & & -.489 & & .433 & & .466 & \\
\hline 7. & I'm pretty good at getting down to work whenever I need to. & & & & .428 & & & .360 & & .407 & \\
\hline 2. & When I'm reading an article or book, I try to find out for myself exactly what the author means. & .430 & & & & & & .392 & & .400 & \\
\hline 13. & I think I'm quite systematic and organised when it comes to revising for exams. & & & & .532 & & & .427 & & .362 & \\
\hline 12. & Often I find myself questioning things I hear in lectures or read in books. & .467 & & & & & & .372 & & .322 & \\
\hline 4. & There's not much of the work here that I find interesting or relevant. & & & .767 & & & .999 & & & -.272 & \\
\hline 18. & I often worry about whether I'll ever be able to cope with the work properly. & & .707 & & & & & & .521 & & .479 \\
\hline 14. & Often I feel I'm drowning in the sheer amount of material we're having to cope with & & .301 & & & & & & .314 & & .434 \\
\hline 16 & I'm not really sure what's important in lectures, so I try to get down all I can. & & .367 & & & & & & .408 & & .421 \\
\hline 15. & Ideas in course books or articles often set me off on long chains of thought of my own. & & .283 & & & & & & .308 & & .375 \\
\hline 1. & I often have trouble in making sense of the things I have to remember & & .341 & & & & & & .382 & & .346 \\
\hline & Much of what I'm studying makes little sense: it's like unrelated bits and pieces. & & & .372 & & & & & .322 & & .286 \\
\hline Varia & e explained $(\%)$ & 19.4 & 9.7 & 7.3 & 6.6 & 5.5 & 26.2 & 11.8 & 6.7 & 19.3 & 10.0 \\
\hline A & & - & - & - & - & - & - & - & - & .74 & .52 \\
\hline
\end{tabular}

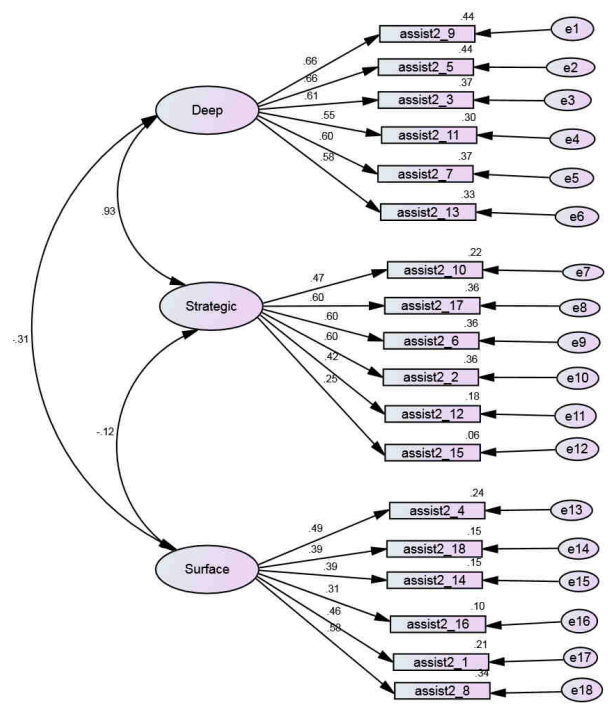

Figure 1 Standardized estimates of the model from ASSIST scores

In computing the CFA for goodness of fit, one of the results from the output is the chisquare. It is argued that the chi-square has limitations and therefore it is not a good indicator of goodness of fit because on the one hand it rejects a hypothesised model even if differences of data from normality are small (West, Finch, \& Curran, 1995) while on the other it is sensitive to sample size and will therefore reject a model even if discrepancies in the model have no theoretical basis (Bentler \& Bonett, 1980; West et al., 1995). In this regard, literature e.g. (Hu \& Bentler, 1999) recommends other goodness of fit statistics, such as the Tucker-Lewis fit index (TLI), Comparative fit index (CFI), and the Root mean squared error of approxima- 
tion (RMSEA). These authors have suggested that for a good fit the different values should be of the order: TLI > .95, CFI > .95 and RMSEA $<.06$ for continuous data $(\mathrm{Hu} \&$ Bentler, 1999). With respect to the RMSEA Browne and Cudecks (1993) furthermore point out that a value of 0.08 or smaller indicates an acceptable fit statistic.

The Chi square $(\chi 2)$ was statistically significant $\left[\chi^{2}=210.94\right.$, $\left.\mathrm{df}=132, p<.0001\right]$. Here the goodness of fit statistics were: $\mathrm{TLI}=.948$, the CFI $=.947$, and the RMSEA $=.054$. Figure 1 shows the standardized parameter estimates of the model from the ASSIST questionnaire. The estimates reveal small and negative associations $R^{2}=-0.31$ between the Surface approaches and Deep approaches as well as between Surface approaches and Strategic approaches $\left(R^{2}=-0.12\right)$. On the other hand, there is a positive association between Deep approaches and Strategic approaches $\left(R^{2}=0.93\right)$.

\section{Discussion and conclusion}

In this study, the main purpose was to establish the reliability and validity of ASSIST Short Version. In terms of reliability of scores from the instrument, it was found that the alpha values ranged between .75 and .83 (preliminary data phase) as well as .65 and .82 (postintervention data phase). In respect of this instrument, the alpha values were accepted for this study because they were comparable to those reported in literature (c.f. Abedina, et al., 2013; Entwistle, et al., 2006; Speth, et al., 2007).

Validity was computed through factor analysis (content validity) and confirmatory factor analysis (construct validity). Before computing the factor structure of the ASSIST, KaiserMeyer-Olkin (KMO) and Bartlett's test of sphericity were determined. The two values reported in this study indicated that computing the factor analysis was appropriate for the data (Field, 2005). Using the Direct oblimin rotation consistently as in reported literature (c.f. Entwistle, et al., 2006; Speth, et al., 2007) a three factor solution was accepted in this study. The three factors were Surface approaches (Factor 1); Deep approaches (Factor 2) and Strategic approaches (Factor 3). Because these factors were consistent with those reported in literature content validity was acceptable in this study. It is argued that a researcher may specify the number of factors in a model based on what is reported in literature (Abedina, et al., 2013; Stevens, 2002; Tabachnick \& Fidell, 2001). In this study, construct validity was assured be- 
cause confirmatory factor analysis indicated that the data could indeed be split into three factors.

The fact that a five factor solution did not make theoretical sense and was therefore abandoned is understandable. This is because it is reported in literature (e.g., Hayton, Allen, \& Scarpello, 2004) that the default setting of eigenvalue greater than unity in SPSS is known to overestimate the number of latent factors. Also, it is argued that "[A] factor with fewer than three items is generally weak and unstable..." (Costello \& Osborne, 2005, p. 5). In this study therefore Factor 3 was seen to be weak and unstable.

In the initial analysis default settings in SPSS such as the eigenvalue greater than unity criterion as well as the scree plot were specified. The rotated matrix produced a five factor solution. It may appear that some of the alpha values in the ASSIST questionnaire were low and therefore not acceptable. However, these values were similar to those reported in literature. For example, in reporting findings using the same questionnaire Diseth (2001, p. 385) wrote " $\ldots \alpha$ values for some of the subscales are relatively low, but they are nevertheless considered sufficient considering that each subscale comprises only four items".

It may be argued that there was something different about the South African sample based on item 4 which is a Surface approach. In terms of item 4, there is not much of the work here that I find interesting or relevant', the results showed that it was loaded with the items consistent with Deep and Strategic approaches. Meanwhile, Item 15 'Ideas in course books or articles often set me off on long chains of thought of my own' loaded with the items consistent with Surface approach while it is a Deep approach item. In this regard, it may be argued that students in this study approach learning in different perspective depending on the nature of the work they are dealing with. It is pointed out that students who follow surface approaches tend to memorise facts, they do not fit them into context and they aim for routine solution methods without attempting to understand (Abedina, et al., 2013).

In this study the aim was to assist students following lower order learning approaches and assist them to achieve. In this case these activities helped students reach the level of deep and strategic approaches. This is consistent with the view that students following surface approaches need to grasp more basic principles in order to work with more complex principles (Abedina, et al., 2013; Duff, 2004). It may be argued that in some instances students followed the surface approach in to understand and unpack the long chains of thought on their own. 
Therefore, the activities were designed in the manner that accommodates all the approaches to learning.

The goodness of fit values of the TLI, CFI, and the RMSEA indicate a good fit between the model and the observed data. For instance, based on Browne and Cudecks' (1993) contention that values of the RMSEA that are 0.08 or smaller indicate acceptable fit, the value of 0.054 obtained in this study was therefore acceptable.

\section{Recommendations}

This article focused on the reliability and validity of scores from the ASSIST Short Version, for students taking mathematics in a South African university. While the results are promising, it is recommended that further studies should be conducted on different samples within the South African context. Such studies will be useful in verifying the findings reported here. Importantly, though, this study adds to the body of knowledge that has addressed the issue of the reliability and validity of ASSIST.

\section{References}

Abedina, N. F. Z., Jaafarb, Z., Husainc, S., \& Abdullahd, R. (2013). The validity of ASSIST as a measurement of learning approach among MDAB students. Procedia - Social and Behavioral Sciences, 90, 549-557. doi: 10.1016/j.sbspro.2013.07.125

Arbuckle, L. (2004). Amos 5.0 [Computer software]. Chicago: SPSS.

Bentler, P. M., \& Bonett, D. G. (1980). Significance tests and goodness-of-fit in the analysis of covariance structures. Psychological Bulletin, 88, 588-606. doi:10.1037/00332909.88.3.588

Biggs, J. (1994). Student learning research and theory - where do we currently stand? Retrieved from http://www.julianhermida.com/algoma/scotlteachingarticlesjbiggs1.pdf.

Biggs, J. B. (1987). Students approaches to learning and studying. Melbourne: Australian Council for Educational Research Limited.

Bolkan, S., Goodboy, A. K., \& Griffin, D. J. (2011). Teacher Leadership and Intellectual Stimulation: Improving Students' Approaches to Studying through Intrinsic Motivation. Communication Research Reports. 28(4), 337-346.

doi: 10.1080/08824096.2011.615958 
Browne, M. W., \& Cudeck, R. (1993). Alternative ways of assessing model fit. In K. A. Bollen \& S. Long (Eds.), Testing Structural Equation Models (pp. 136-162). Newbury Park CA: Sage.

Buckley, A. C., Pitt, E., Norton, B., \& Owens, T. (2010). Students' approaches to study, conceptions of learning and judgements about the value of networked technologies. Active Learning in Higher Education, 11(1), 55-65. doi: 10.1177/1469787409355875

Costello, A. B. \& Osborne, J. W. (2005). Best practices in exploratory factor analysis: Four recommendations for getting the most from your analysis. Practical Assessment, Research \& Evaluation, 10 (7), 1-9. Retrieved from http://pareonline.net/getvn.asp?v= $10 \& n=7$

Cronbach, L. J. (1951). Coeffiecient alpha and the internal structure of tests. Psychometrika, 16, 297-334. doi: 10.1007/BF02310555

Diseth, A. (2001). Validation of a Norwegian Version of the Approaches and Study Skills Inventory for Students (ASSIST): Application of structural equation modelling. Scandinavian Journal of Educational Research, 45(4), 381-394. doi: 10.1080/00313830120096789

Diseth, Å., \& Martinsen, Ø. (2003). Approaches to Learning, Cognitive Style, and Motives as Predictors of Academic Achievement. Educational Psychology, 23(2), 195-207. doi: $10.1080 / 01443410303225$

Ditcher, A. K. (2001). Effective teaching and learning in higher education, with particular reference to the undergraduate education of professional engineers. International Journal of Engineering, 17(1), 24-29.

Duff, A. (2004). The revised approach to learning and studying inventory and its use in the Management education. Active learning in Higher Education, 5(1), 56-72. doi: $10.1177 / 1469787404040461$

Entwistle, N. J. (1996). Assist: approaches and study skills inventory for students. University of Edinburgh: Centre for Research on Learning and Instruction.

Entwistle, N. (2000). Promoting deep learning through teaching and assessment: Conceptual frameworks and educational contexts. Proceedings of the TLRP Conference, TLRP (pp. 1-12)

Entwistle, N., McCune, V., \& Tait, H. (2006). Approaches to study skills inventory for students (ASSIST). USA: Napier University.

Entwistle, N. J., and Ramsden, P. (1983). Understanding Student Learning. London: Croom Helm 
Felder, M., \& Brent, R. (2005). Understanding student differences. Journal of Engineering Education, 94 (1), 57-72. doi: 10.1002/j.2168-9830.2005.tb00829

Field, A. (2005). Discovering Statistics Using SPSS (2nd ed.). London: SAGE.

Gadelrab, F. H. (2011). Factorial structure and predictive validity of approaches and study skills inventory for students (ASSIST) in Egypt: A confirmatory factor analysis approach. Electronic Journal of Research in Educational Psychology, 9(3), 1197-1218.

Gliem, J. A., \& Gliem, R. R. (2003). Calculating, interpreting, and reporting Cronbach's alpha reliability coefficient for Likert-type scales. Paper presented at the Midwest Research-to-Practice Conference in Adult, Continuing, and Community Education, Columbus, $\mathrm{OH}$.

Golafshani, N. (2003). Understanding reliability and validity in qualitative research. The Qualitative Report, 8(4), 597-607.

Hailikari, T. K., \& Parpala, A. (2014). What impedes or enhances my studying? The interrelation between approaches to learning, factors influencing study progress and earned credits. Teaching in Higher Education, 19(7), 812-824.

doi: $10.1080 / 13562517.2014 .934348$

Hayton, J. C., Allen, D. G., \& Scarpello, V. (2004). Factor retention decisions in exploratory factor analysis: A tutorial on parallel analysis. Organizational Research Methods, 7, 191-205. doi: 10.1177/1094428104263675

Hu, L. T., \& Bentler, P. M. (1999). Cut off criteria for fit indexes in covariance structure analysis: Conventional criteria versus new alternatives. Structural Equation Modeling, 6, 1-55. doi: 10.1080/10705519909540118

Marland, J., Dearlove, J., \& Carpenter, J. (2015). LASSI: An Australian evaluation of an enduring study skills assessment tool. Journal of Academic Language and Learning, 9(2), A32-A45.

Martin, F., \& Säljö, R. (1976). On qualitative difference in learning: 1 Outcomes and process. British Journal of Educational Psychology, 46, 4-11. doi: 10.1111/j.2044-8279.1976.tb02980.x

Mattick, K., Dennis, I., \& Bligh, J. (2004). Approaches to learning and studying in medical students: validation of a revised inventory and its relation to student characteristics and performance. Medical Education, 38, 532-543. doi: 10.1111/j.1365-2929.2004.01836.x

McMillan, J. H., \& Schumacher, S. (2001). Research in education: A conceptual introduction. New York: Longman. 
Miller, M. J. (n.d.). Reliability and validity. Western International University.

Mnisi, S. (2015). Exploring a teaching strategy using clicker mobile technology for active learning in undergraduate mathematics classes. Doctoral in Education, Tshwane University of Technology, Pretoria.

Mogashana, D., Case, J. M., \& Marshall, D. (2012). What do student learning inventories really measure? A critical analysis of students' responses to the Approaches to Learning and Studying Inventory. Studies in Higher Education, 37(7), 783-792. doi: $10.1080 / 03075079.2011 .629294$

Morse, J. M., Barrett, M., Mayan, M., Olson, K., \& Spiers, J. (2002). Verification strategies for establishing reliability and validity in qualitative research. International Journal of Qualitative Methods, 1(2), 1-19. doi: 10.1177/160940690200100202

Price, L., Richardson, J. T. E., Robinson, B., Ding, X., Sun, X., \& Han, C. (2011). Approaches to studying and perceptions of the academic environment among university students in China. Asia Pacific Journal of Education, 31(2), 159-175.

Reynaldo, J., \& Santos, A. (1999). Cronbach's Alpha: A tool for assessing the reliability of scales. Journal of Extention, 37(2), 1-4. doi: 10.1080/02188791.2011.566996

Ro, H. K., Merson, D., Lattuca, L. R., \& Terenzini, P. T. (2015). Validity of the Contextual Competence Scale for Engineering Students. Journal of Engineering Education, 104(1), 35-54. doi: 10.1002/jee.20062

Roblyer, M. D., McDaniel, M., Webb, M., Herman, J., \& Witty, J. V. (2010). Findings on facebook in higher education: A comparison of college faculty and student uses and perceptions of social networking sites. Internet and Higher Education, Vol. 10, pp $134-140$.

Säljö, R. (1981). Learning approach and outcome: Some emperical ebservations. Instructional Science, 10(1), 47-65. doi: 10.1007/BF00124566

Säljö, R. (2004). Learning and technologies, people and toolsin co-ordinated activities. International Journal of Educational Research, 41, 489-494.

doi: 10.1016/j.ijer.2005.08.013

Schreiber, J. B., Stage, F. K., King, J., Nora, A., \& Barlow, E. A. (2006). Reporting structural equation modeling and confirmatory factor analysis results: A review. The Journal of Educational Research, 99(6), 323-337. doi: 10.3200/JOER.99.6.323-338

Simelane, S., Mji, A., \& Mwambakana, J. (2011). Clicker-technology teaching strategy and students approaches to learning in syncronized activities. Proceedings of the World 
Conference on E-Learning in Corporate, Government, Healthcare, and Higher Education, Honolulu, AACE (pp. 1708-1713).

Speth, C., Lee, D., \& Hain, P. (2003). Get an ASSIST and support students' learning online. Proceedings of the 19th Annual Conference on Distance Teaching and Learning, Regents of the University of Wisconsin System (pp. 1-6).

Speth, C., Namuth, D. M., \& Lee, D. (2007). Using ASSIST short form for evaluation an information technology application: Validity and Reliability issues. Information Science Journal, 10, 107-119.

Stevens, J. (2002). Applied multivariate statistics for the social sciences (3rd ed.). Mahwah, NJ: Erlbaum.

Tabachnick, B. G., \& Fidell, L. S. (2001). Using multivariate statistics (4th ed.). Boston: Allyn \& Bacon.

Tavakol, M., \& Dennick, R. (2011). Making sense of Cronbach's alpha. International Journal of Medical Education, 2, 53-55. doi: 10.5116/ijme.4dfb.8dfd

Teixeira, C., Gomes, D., \& Borges, J. (2013). The approaches to studying of Portuguese students of introductory accounting. Accounting Education, 22(2), 193-210. doi: $10.1080 / 09639284.2013 .766426$

Tlhapane, M., \& Simelane, S. (2010). Meeting realities in technology-enhanced learning. In S. Mukerji \& P. Tripathi (Eds.), Cases on Transnational Learning and Technologically Enabled Environments (pp. 224-245). USA: IGI.

Trigwell, K., Prosser, M., \& Waterhouse, F. (1999). Relations between teachers' approaches to teaching and students' approaches to learning. Higher Education, 37, 57-70. doi: 10.1023/A:100354831319

Venkatesh, V., Croteau, A. M., \& Rabah, J. (2014). Perceptions of Effectiveness of Instructional Uses of Technology in Higher Education in an Era of Web 2.0. Proceedings of the System Sciences (HICSS), 47th Hawaii International Conference on, (pp. 110119).

Warren, H. (2004). Deep and Surface Approaches to Learning. Retrieved from 07/07/2009, from http://www.engsc.ac.uk/er/theory/learning.asp

West, S. G., Finch, J. F., \& Curran, P. J. (1995). Structural equation models with nonnormal variables: Problems and remedies. In R. H. Hoyle (Ed.), Structural equation modeling: Concepts, issues, and applications (pp. 56-75). Thousand Oaks, CA: Sage 